\title{
In vitro study of antifungal effect of Carica papaya peel var. california extract against Candida albicans
}

\author{
Trisnawaty K ${ }^{1}$, Rauna, A.E ${ }^{2}$, Dewi, S.R.P. ${ }^{3}$, Handayani, P. ${ }^{3 *}$ \\ ${ }^{1}$ Biomedical Department, Dentistry, Medical Faculty of Universitas Sriwijaya, Palembang-Indonesia \\ ${ }^{2}$ Dentistry Academic Program, Dentistry, Medical Faculty of Universitas Sriwijaya, Palembang-Indonesia \\ ${ }^{3}$ Oral Medicine Department, Dentistry, Medical Faculty of Universitas Sriwijaya, Palembang-Indonesia \\ *Corresponding author’s email Pudji Handayani: pudji.handayani@fk.unsri.ac.id
}

Received 12 Nopember 2020; accepted 11 Desember 2020

\begin{abstract}
Candida albicans is mostly found in oral cavity as an opportunistic microbiota in some oral mucous diseases. The papaya peel extract is a rich source of antifungal compounds. The aimed of this study was to determine antifungal effect of carica papaya peel extract againts Candida albicans. This study was experimental laboratory with post-test only control group design. The macerated ethanol extract of papaya peel were divided into six groups based on its concentrations. It consisted of 2.5\%, 5\%, 10\%, $20 \%$ concentration of papaya peel extract, nystatin as positive control, and distilled water as negative control. All concentration of papaya peel extracts were effective against the growth of $C$. albicans. The minimum inhibitory concentration was $2.5 \%$. Conclusion of this research shows that the extract of papaya peel var Califonia has antifungal effect against $C$. albicans.
\end{abstract}

Keywords: antifungal, Candida albicans, Carica papaya.

\begin{abstract}
Abstrak
Candida albicans merupakan suatu microbiota oportunistik yang paling banyak ditemukan pada beberapa penyakit mukosa mulut. Ekstrak kulit pepaya kaya akan komponen antijamur. Penelitian ini dilakukan untuk mengetahui efek antijamur ekstrak kulit pepaya terhadap Candida albicans. Penelitian ini merupakan suatu penelitian laboratorium dengan desain post-test only control group. Ekstrak kulit pepaya didapatkan dengan metode maserasi menggunakan etanol yang kemudian dibagi menjadi 6 kelompok dengan berbagai konsentrasi. Konsentrasi ekstrak yang digunakan adalah 2,5\%, $5 \%, 10 \%, 20 \%$, dengan nystatin sebagai kontrol positif dan akuades sebagai kontrol negatif. Hasil Penelitian menunjukkan bahwa semua konsentrasi ekstrak kulit papaya efektif dalam menghambat pertumbuhan Candida albicans. Daya hambat minimum yaitu pada konsentrasi 2,5\%. Kesimpulan penelitian ini adalah ekstrak kulit pepaya var. California memiliki efek antifungal terhadap Candida albicans.
\end{abstract}

Kata Kunci: antijamur, Candida albicans, Carica papaya. 


\section{Introduction}

Candida albicans (C. albicans) is a normal microflora in the oral cavity and can turn into opportunistic pathogens that causes oral infections if there are underlying predisposing conditions. These predisposing conditions included decreased body defense, metabolic diseases, immunosuppressive therapy, and Acquired Immunodeficiency Syndrome (AIDS/HIV). ${ }^{1,2}$ As many as $50 \%$ of Oral Candidiasis cases is caused by $C$. albicans. ${ }^{2,3}$ Some clinical findings related to the infection included Pseudomembranous Candidiasis, Erythematous Candidiasis, Leukoplakia Candidiasis, Denture Stomatitis, Angular Cheilitis, Median Rhomboid Glossitis, and HIV-related Oral Candidiasis. $^{4,5}$ Moreover, C. albicans also contributes to the formation of microbial acids which causes glucose and maltose fermentation and produces acids and gases. ${ }^{6}$ The presence of the fungus $C$. albicans can increase with the attachment of Streptococcus mutans to biofilms and dental caries substances. $C$. albicans have significant contribution to the pathogenesis of active caries in children. ${ }^{6,7}$

Treatment of infections caused by $C$. albicans is antifungals. Along with the increasing cases of Candidiasis, treatment with synthetic materials has been widely developed. However, there are side effects of synthetic antifungal drugs such as nystatin, amphotericin B, ketoconazole, and fluconazole. Furthermore, there are side effects of synthetic antifungal drugs, in which continuous use can cause drug resistance. Therefore, other treatment modalities are needed to reduce these side effects by using herbal medicines as an alternative treatment. ${ }^{8}$

Papaya (Carica papaya) is known to be one of the plants that has benefits in curing diseases. The parts of papaya plants that can be used as herbal medicines include the fruit, leaves, and flowers. Yogiraj et al. (2014) mentioned that parts of papaya plants including leaves, seeds, latex, and fruit have medical value. ${ }^{9}$ The peel of raw papaya fruit is known to contain flavonoids, phenols, tannins, saponins, and antioxidant properties as antibacterial and antifungal. ${ }^{10-13}$ Based on the research of Egbuonu et al. (2017), 10\% ethanol extract of raw papaya peel of Agric variety can inhibited the growth of $C$. albicans $20 \mathrm{~mm}$. This can be due to high active compound in papaya peel of Agric variety. ${ }^{14}$

In Indonesia, there were various types of papaya, but the most frequent and the most common type of papaya was the Californian variety. Based on this explanation, further study needs to be conducted to understand the potential antifungal effect of raw papaya peel extract (Carica papaya) of California variety in Indonesia. This in vitro study was aimed to determine the antifungal effect and determine the minimum inhibitory concentration (MIC) of papaya peel extract of Californian variety against $C$. albicans.

\section{Methods}

\section{Preparations of Papaya Peel Extract}

Raw papaya of Californian variety was bought from farmers and washed with tap water. The papaya skin was peeled with peeler then air dried for 3 hours and dried in the oven for 3 days at $40^{\circ} \mathrm{C}$. The dried papaya peel then mashed up using blender to form powder. The obtained powder was then extracted using maceration method, immersed in $96 \%$ ethanol solution at room temperature and stored in a place free of sunlight. The solution was immersed for 3 days while stirred occasionally, then 
filtered with Whatman paper. After filtering, ethanol filtrate was then evaporated with a rotary evaporator at $40^{\circ} \mathrm{C}$ with rotational speed of $77 \mathrm{rpm}$, to eliminate excess solvents to obtain thick extract of papaya peel. The extract Carica papaya var. California peel was made into 4 concentration; $2.5 \%, 5 \%$, $10 \%$, and $20 \%$ that were used in this study.

\section{Phytochemical Test of Californian Papaya Peel Extract}

The evaluation of bioactive compound of Carica papaya var. California peel was done by phytochemical Screening. The result of phytochemical screening of Carica papaya var. California peel were positive for alkaloids, steroid, and tannin.

\section{Preparations of $\boldsymbol{C}$. albicans Media}

Six grams of Saboraud Dextrose Agar (SDA) were put into Erlenmeyer flask and $180 \mathrm{ml}$ of sterile distilled water was added. The media was heated to dissolve the whole agar. The media was autoclaved at $121^{\circ} \mathrm{C}$ for 15 minutes. Afterwards, the media was poured into petri dishes and allowed to stand until the media solidified.

\section{Preparations of $\quad C$. albicans Suspension}

Some fungal colonies were taken from $C$. albicans culture on SDA media using a transfer loop. The transfer loop was dipped into a test tube containing $\quad 0.9 \% \quad \mathrm{NaCl}$ until homogeneous. The test tube was covered with cotton and incubated for 24 hours at $37^{\circ} \mathrm{C}$. The solution was then compared to Mac Farland 0.5 standard. If the turbidity is still lacking, $C$. albicans can be added, otherwise then the solution can be diluted again. The obtained $C$. albicans suspension turbidity was in accordance to Mac Farland 0.5 standards or proportional to the number of fungal $1.5 \times 108 \mathrm{CFU} / \mathrm{ml}$. C. albicans suspension was then taken by dipping a cotton swab into the solution and then scraping it into 5 petri dishes containing SDA media evenly.

Antifungal Effect Test (Disc Diffusion) This study was aimed to determine the antifungal effect of papaya peel extract of California variety against clinical isolates of $C$. albicans using agar discs diffusion test method (Kirby-Bauer) with $6 \mathrm{~mm}$ diameter disc paper. Five petri dishes containing $C$. albicans in the media was prepared. Paper disc was soaked for 15 minutes in each treatment extract concentrations of $2.5 \%, 5 \%, 10 \%, 20 \%$, positive control, and negative control. Then the disc paper was taken using nippers and placed above the agar that has been smeared with $C$. albicans. Five petri dishes containing $C$. albicans were placed with 4 variations of the extract concentration $(2.5 \%, 5 \%, 10 \%$, and $20 \%$ ), positive control, and negative control. Then the petri dishes were incubated for 24 hours at $37^{\circ} \mathrm{C}$. The formation of clear zone was observed in the petri dishes and were measured using calipers. Clear zone area that formed showed the amount of inhibition of papaya peel extract against $C$. albicans. The primary data results obtained were analyzed and described descriptively.

\section{Results}

Phytochemical test results of the ethanol extract of Californian papaya peel in showed that the ethanol extract of papaya peel contains alkaloids, tannins, and steroids. These results was in line with the previous study of Lydia et al. (2016) and Shiddique et al. (2017). ${ }^{12,15}$ 
However, it was different from studies conducted by Dada et al. (2016) and Chukwuka et al. (2013), which stated that papaya peel extracts contained phytochemical compounds such as saponins and flavonoids, while this study did not indicate the presence of these compounds. ${ }^{10,11}$ Based on the study by Chukwuka et al. (2013), raw papaya peel extract has high saponin content, ${ }^{10}$ which according to Alfiah et al. (2015), saponin is a compound that works by disrupting the stability of the fungal cell membrane which lead to cell membrane damage and causes various important components from the fungal cell to be released, such as protein, nucleic acids and nucleotides. ${ }^{16}$ According to Alves et al. (2016), flavonoids work by inhibiting the synthesis of fungal cell walls because it has trimethoxflavone (TMF) which inhibits fungal growth. Flavonoid activity also prevents ergosterol from binding to the fungal cell membrane. Ergosterol is an important sterol in fungal filaments and yeast for fungal nutrition. ${ }^{17,18}$

The difference in the phytochemical results of the papaya peel extract might be caused by the different of papaya varieties. According to Abdullah et al. (2010), the various types of papaya caused the active compounds contained also vary, the difference in the amount and type of content of the active compound also depends on the age of the plant. ${ }^{19}$ The statement was supported by Chukwuka et al. (2013), in terms of differences in age (maturity stage) of the papaya. Raw papaya peel has a higher active compound content compared to mature or very mature stage of papaya. ${ }^{10}$

\section{Inhibition Test of $C$. albicans Using Discs Diffusion Method}

This study consisted of six treatment groups, i.e. papaya peel extract with concentrations of $2.5 \%, 5 \%$, $10 \%, 20 \%$, positive control, and negative control with 5 replications. The results of the inhibition zone measurements of all treatments are written in millimeters $(\mathrm{mm})$ that can be seen in Table 1.

Table 1. Mean and Standard Deviation of Inhibited Zones of Raw Papaya Peel Extract against $C$. albicans

\begin{tabular}{lcllll}
\hline \multicolumn{1}{c}{ Group } & Total & $\begin{array}{l}\text { Mean } \\
(\mathbf{m m})\end{array}$ & SD & Min* & Max** \\
\hline $\mathbf{2 , 5 \%}$ & 5 & 1.56 & 2.96 & 0 & 6.8 \\
$\mathbf{5 \%}$ & 5 & 0.88 & 0.52 & 0 & 1.4 \\
$\mathbf{1 0 \%}$ & 5 & 1.2 & 1.64 & 0 & 4 \\
$\mathbf{2 0 \%}$ & 5 & 0.8 & 0.83 & 0 & 2 \\
Control (+) & 5 & 5.67 & 3.14 & 3 & 10.7 \\
Control (-) & 5 & 0 & 0 & 0 & 0 \\
\hline
\end{tabular}

*Minimum

**Maximum

Based on Table 1, it can be seen that the highest inhibitory zone of papaya peel extract is found at $2.5 \%$ concentration with mean of $1.56 \mathrm{~mm}$ $(\mathrm{SD} \pm 2.96)$. However, the inhibition zone decreased when the extract concentration was increased to $5 \%, 10 \%$, and $20 \%$, the inhibition zone decreased to $0.8 \mathrm{~mm}$ ( $\mathrm{SD} \pm 0.83$ ). The positive controls had an average inhibition zone greater than all extract concentrations while the negative controls did not show any inhibitory zone. The inhibition zone diameter of California papaya peel extract against the growth of clinical $C$. albicans isolates can be seen in Figure 2. 


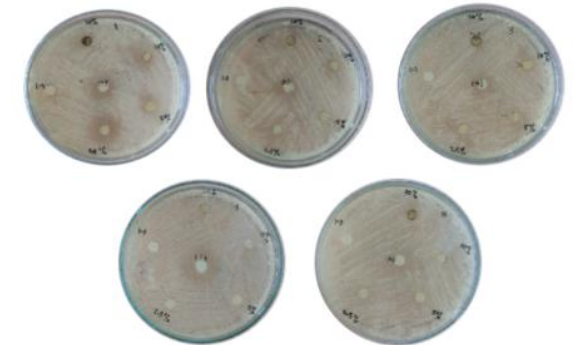

Figure 2. Inhibition Zones of Raw Papaya Peel Extract against $C$. albicans

Inhibition zones are formed due to the presence of active substances contained in papaya peel such as tannins, alkaloids, and steroids. Tannin is a polyphenol group compound that works with the target of fungal cell wall polypeptide which causes damage to the fungal cell wall and causes increase to fungal cell permeability, thus fungal growth is inhibited. ${ }^{20}$ Alkaloids also have antimicrobial activity due to $\mathrm{pH}>$ 7 with alkaline properties that can inhibit the RNA and DNA polymerization and fungal cell protein synthesis. Therefore, the growth of $C$. albicans can be suppressed. ${ }^{15,17}$ Steroids can inhibit fungal growth, through the cytoplasm of the fungal cell or interfere with the growth and development of fungal spores. Steroids have lipophilic properties that can inhibit spore germination. ${ }^{16}$

\section{Discussion}

Based on the results of the inhibition zone, it can be seen that increasing the concentration of papaya peel extract does not always increasing the diameter of the inhibition zone. The results of this study are similar to study conducted by Fitriani et al. (2012), that the increased concentration of the Salam leaf extract (Syzygium polyanthum (wight) walp.) was not always able to increase the inhibitory zone against $C$. albicans. This is because the higher the concentration of the extract the greater the molecules that were formed. Therefore, there is no direct contact between the active compound and the fungi due to the difficult diffusion process. ${ }^{21}$ According to Setiorini et al. (2014), determination of Minimum Inhibitory Concentration (MIC) is based on the lowest concentration of extract that produced inhibition zone. Based on the results, the MIC of ethanol extract of papaya peel against $C$. albicans is $2.5 \% .^{22}$

According to the theory suggested by Davis and Stout (1971), the diameter of the inhibitory zone formed in the in vitro test of 0 to $4 \mathrm{~mm}$ was categorized as weak. ${ }^{23}$ Thus, the antifungal effect from this study was relatively weak. The weak antifungal effect in this study was different from the study conducted by Egbuonu et al. (2017), which showed that the $10 \%$ ethanol extract of raw papaya peel of Agric variety can inhibit the growth of C. albicans by $20 \mathrm{~mm} .{ }^{14}$ The large inhibitory zone suggested that the ethanol extract of raw papaya peel of Agric variety have a relatively strong antifungal effect. ${ }^{23}$ Hilzon CF (2016) stated that papaya peel extract with $30 \%$ concentration inhibited $C$. albicans zone by $13 \mathrm{~mm} .{ }^{24}$ The antifungal effect was categorized as strong, while this study 
showed that $20 \%$ papaya peel extract had weak antifungal effect. Californian papaya peel has a small antifungal effect compared to other parts of papaya such as leaves and seeds. ${ }^{25,26}$

The weak inhibition of papaya peel extract indicated the lack of concentration of the compounds contained in the extract, thus the effect antifungal was not optimal. The active compound which is absorbed in the disc paper is suspected to be not optimal due to an imperfect dilution process. The extract that was used was too thick and sticky thus cannot dissolve completely in distilled water, causing granules within the extract. The differences in the inhibition zone in this study and previous studies might be caused by various factors, one of these can be caused by differences of types and amounts of active compounds present in this study, that can influence the result of antifungal effect. The different types and amounts of active compounds are influenced by the variety, stage, and environment in which papaya grows, such as ambient temperature, humidity, adequate sunlight, and water availability. The quality of an extract depends by the type and the number of chemical compounds it contains, the way it was extracted, and the selection of the solvent. ${ }^{24}$

The difference in antifungal effects in this study compared to previous studies might have been caused of $C$. albicans isolates that are different from $C$. albicans isolates used by previous studies. The inhibitory zone of positive controls observed from this study, was not in accordance with inhibitory zone in general positive controls. It might be assumed that the $C$. albicans isolate in this study was not a standard isolate but a clinical isolate and might have started resistance caused by drug storage factors.

\section{Conclusion}

Based on these results, the ethanol extract of raw papaya peel (Carica Papaya) of Californian variety has a weak antifungal effect with MIC value of $2.5 \%$ against Candida albicans in vitro.

Other dilution agents should be used to dissolve the thick and sticky extract so that the extract can be dissolved homogeneously and phytochemical quantitative tests are required to determine the number of compounds contained in Californian papaya peel extracts

\section{Acknowledgement}

This research was funded by "Lembaga Penelitian dan Pengabdian Masyarakat" (LPPM) Universitas Sriwijaya, contract number:

0146.98/UN9/SB3.LP2M.PT/2019.

\section{References}

1. Nejad BS, Rafiei A, Moosanejad F. Prevalence of candida species in the oral cavity of patients with periodontitis. African J Biotechnol. 2011;10(15):2987-90.

2. Patil S, Rao R, Majumdar B, Anil S. Clinical appearance of oral candida infection and therapeutic strategies. Front Microbiol. 2015;6(1391):1-10.

3. Getas I, Wiadnya I, Waguriani L. Pengaruh penambahan glukosa dan waktu inkubasi pada media sda (sabaroud dextrose agar) terhadap pertumbuhan jamur candida albicans. Media Bina Ilm. 2014;8(1):51-7.

4. Glick M. Burket's oral medicine. 12th ed. USA: People's Medical Publishing House; 2015. 93-96 p.

5. Kalista K, Chen L, Wahyuningsih R, Rumende C. Karakteristik klinis dan prevalensi pasien kandidiasis invasif di rumah sakit cipto mangunkusumo. J Penyakit Dalam Indones. 2017;4(2):56-61. 
6. Klinke T, Kneist S, Soet J, Kuhlisch E, Mauersberger S, Forster A, et al. Acid production by oral strains of candida albicans and lactobacilli. Caries Res. 2009;43:83-91.

7. Barbieri D de, Vicente VA, Fraiz FC, Lavoranti OJ, Svidzinski T, Pinheiro RL. Analysis of the in vitro adherence of streptococcus mutans and candida albicans. Brazilian Journal of Microbiology. Brazilian J Microbiol. 2007;38:624-31.

8. Garcia-cuesta C, Sarrion-Pérez M-G, Bagán J V. Current treatment of oral candidiasis: a literature review. J Clin Exp Dent. 2014;6(5):576-82.

9. Yogiraj V, Goyal PK, Chauhan CS, Goyal A, Vyas B. Carica papaya linn : an Overview. Int J Herb Med. 2015;2(5):1-8.

10. Chukwuka KS, Iwuagwu M, Uka UN. Evaluation of nutritional components of carica papaya 1 . at different stages of ripening. IOSRJPBS. 2013;6(4):13-6.

11. Dada FA, Nzewuji FO, Esan AM, Oyeleye SI, Adegnola VB. Phytochemical and antioxidant analysis of aqueous extracts of unripe pawpaw (Carica papaya Linn.) Fruit's peel and seed. IJRRAS. 2016;27(3):68-71.

12. Lydia E, Riyazudin M, John S, Thiyagarajan S. Investigation on the phytochemicals present in the fruit peel of carica papaya and evaluation of its antioxidant properties. Int $\mathbf{J}$ Heal Allied Sci. 2016;5:247-52.

13. Siddique S, Nawaz S, Muhammad F, Akhtar B, Aslam B. Phytochemical screening and in-vitro evaluation of pharmacological activities of peels of musa sapientum and carica papaya fruit. Nat Prod Res [Internet]. 2018;32(11):1333-6. Available from:

https://doi.org/10.1080/14786419.20 17.1342089

14. Egbuonu ACC, Ike AC, Onyeabo C, Okechukwu RC. Comparative Assessment of Some Nutritive and Antifungal Properties of Milled Carica papaya Peels and Seeds.
European J Med Plants. 2017;18(1):1-7.

15. Rezeki S, Chismirina S, Iski A. Pengaruh ekstrak daun sirih merah (piper crocatum) terhadap pertumbuhan candida albicans. J Syiah Kuala Dent Soc. 2017;2(1):52-62.

16. Alfiah RR, Khotimah S, Turnip M. Efektivitas ekstrak metanol daun sembung rambat (mikania micrantha kunth) terhadap pertumbuhan jamur candida albicans. Protobiont. 2015;4(1):52-7.

17. Arif T, Bhosale JD, Kumar N, Mandal TK, Bendre RS, Lavekar GS. Natural products - antifungal agents derived from plants. J Asian Nat Prod Res. 2009;11(7):621-38.

18. Filho AA, Oliveira HM, Meireles DR, Maia GL, Filho JM, Júnior JP, et al. In vitro anti-Candida activity and mechanism of action of the flavonoid isolated from praxelis clematidea against candida albicans species. J Appl Pharm Sci. 2016;6(01):66-9.

19. Abdullah MM, Ariowibisono $\mathrm{P}$, Ariefiandy R, Fauzi M, Sutarto. Skrining potensi kulit buah pepaya mentah sebagai obat antimalaria alami. PKMP. 2000;172-4.

20. Rahmi A, Roebiakto E, Leka L. Potensi ekstrak rimpang kencur (kaempferia galanga 1.) menghambat pertumbuhan candida albicans. MLTJ. 2016;2(2):70-6.

21. Fitriani A, Hamdiyati Y, Engriyani R. Aktivitas antifungi ekstrak etanol daun salam (syzygium polyanthum (wight) walp.) terhadap pertumbuhan jamur candida abicans secara in vitro. Biosfera. 2012;29(2):71-9.

22. Setiorini MS, Soegihardjo CJ, Atmodjo K. Potensi pengaruh antimikroba krim ekstrak patah tulang (euphorbia tirucalli linn.) terhadap propionibacterium acnes atcc 11827 dan candida albicans atcc 24433. J Farm Sains dan Komunitas. 2014;11(2):64-71.

23. Kandoli F, Abijulu J, Leman M. Uji 
daya hambat ekstrak daun durian (durio zybethinus) terhadap pertumbuhan candida albicans secara in vitro. J Ilm Farm. 2016;5(1):46-52.

24. Fugaban-Hizon C. Comparative study on the antifungal property of banana and papaya peel extract on candida albicans when added to glucose yeast peptone agar. SAJB. 2016;4(2):154-7.

25. Ajah HA. In vitro and in vivo studies on the anticandidal activity of carica papaya seed extract. Eur J Biol Med Sci Res. 2015;3(3):33-45.

26. Rosari IR, Zulfian, Sjahriani. Pengaruh ekstrak daun pepaya (carica papaya 1.) terhadap pertumbuhan candida albicans. J Ilmu Kedokt dan Kesehat. 2014;1(2):127-34. 